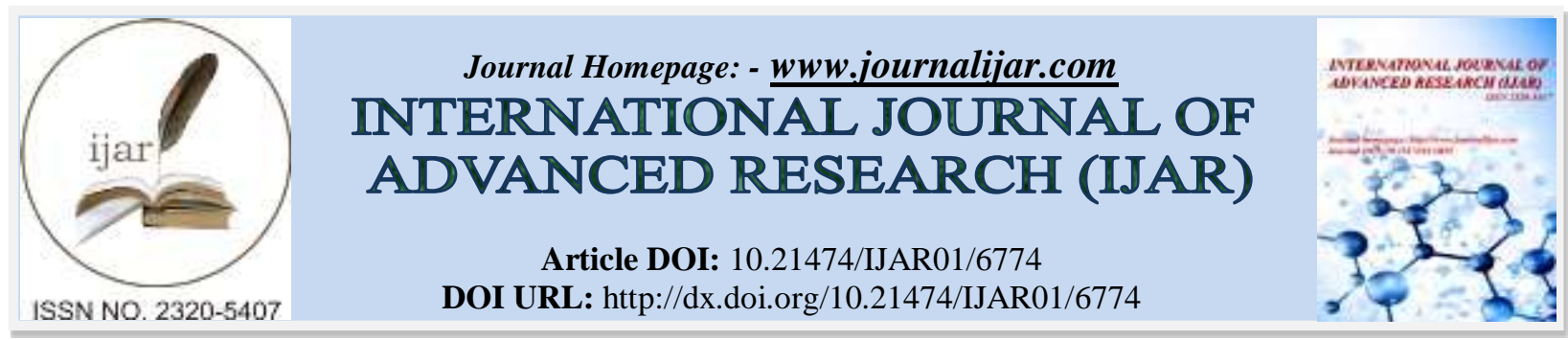

RESEARCH ARTICLE

\title{
DISTRIBUTED ENERGY RESOURCES:ISSUES AND CHALLENGES.
}

\author{
Deeksha Sanwal ${ }^{1}$, Disha Gusain ${ }^{1}$, Leena G. ${ }^{1}$ and Mohit Verma ${ }^{1,2}$. \\ 1. Department of Electrical and Electronics Engineering, Manav Rachna International University, Faridabad, \\ Haryana, India. \\ 2. Accendere KMS-CL Educate Ltd., New Delhi, India.
}

\section{Manuscript Info}

Manuscript History

Received: 18 January 2018

Final Accepted: 20 February 2018

Published: March 2018

Keywords:-

DER, Microgrid.

\section{Abstract}

It is noticed, a hike in percentage over the smart grid interests in producers and consumers. In order to meet the requirements of the consumption of power we need to increase the use of renewable energy resources. Distributed Energy Sources (DER) is quite attractive way of distributing energy. It has got great future scope in distribution area. In the present paper the characteristics, advantages and disadvantages of various DER sources is discussed. The challenges and issues of DER are also described and addressed the problems that arise in existing grid.

Copy Right, IJAR, 2018,. All rights reserved.

\section{Introduction:-}

As increasing demand of electricity in today's era, losses reduction, efficiency enhancement and making grid environment friendly are the necessities. Electricity must be generated, dispersed and distributed in real time. It is required to manage demand and supply in real time as well as ensure stability and power quality to consumers. Smart distribution is distributing energy in a smarter way. One of smarter approaches of distribution is, using micro grids concepts. Micro grids can be functioned in two different modes named as; connected to a grid and stand-alone mode. One of the main attractive features/advantages of these microgrids is its generation facilities, which could be centralized. This helps to provide the smaller and additional dispersed energy resources way and support to overcome the losses of traditional methods on economic scale [1]. Distributed energy resources (DERs) are small power resources, like solar photovoltaic, cogeneration systems, wind turbines, micro turbines, backup generators and energy storage devices that can be aggregated to meet the regular demands. It provides energy where ever it is needed [7]. It also provides the less expensive and fast option as compared to the large structured power plants. Usually, DER producing less than 10megawattenergyand is installed for meeting particular needs. DER system includes wind turbines, photovoltaic system, fuel cells, gas turbines, micro-turbines, internal combustion engines and energy storage system, which helps to enhance the operating ability of the electric grid independently. They are installed adjacent to the electricity consuming units such as home, business etc. and offer an improved alternative to the traditional electric power grid. DER is designed to distribute energy in smarter way to enhance the reliability, reduces cost, increasing efficiency and to meet the future demands of consumers.

\section{Distributed Energy Resources ( Der):-}

A gradually refinement have all been occur in the DER technologies from the past several years. New technologies are highly efficient than the previous ones; therefore a replacement or upgrade may pay for itself sooner than expected. Also, safety of energy is a major issue at many Federal facilities. In those specific cases, DER systems can power mission-critical loads, reduce hazardous or costly power outages, and diversify the local energy supply [2]. 
Bring sources closer to the loads contributes in reduction the heat losses and transmission cost. Existing grid allows one way communication whereas micro grids allow two ways communication as shown in Fig 1 and 2 respectively.

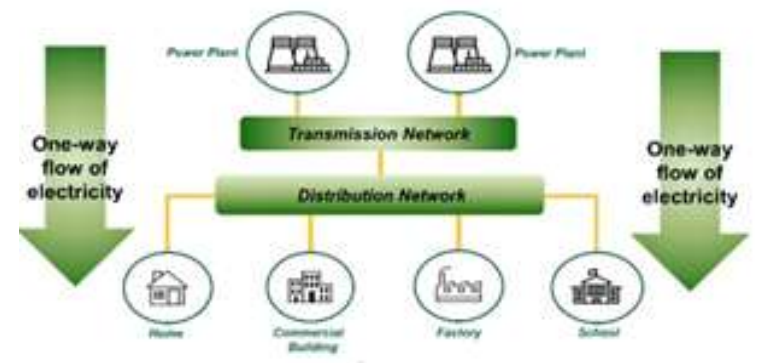

Figure 1. Today's Electrical grid

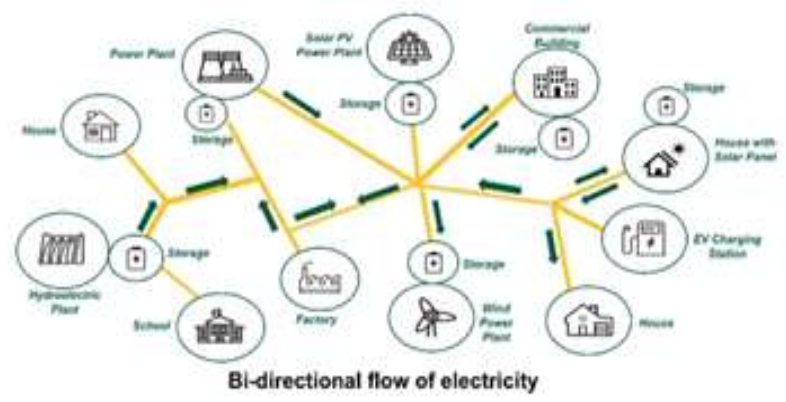

Figure 2. Tomorrow's Electrical grid

The DER system is capable enough to enhance the safety of the bulk power system by confining overcrowding, loop flows, high losses and cascading effects. Specifically, due to the decentralized nature, the distributed resources enhanced the considerable consistency of the system as a whole by making power supply less dependent on the bulk transmission network.

Some DER sources such as micro-turbines, fuel cells are easily controllable, while others (wind and solar energy) having highly unpredictable power output. This necessitates highly and flexible automated distribution systems with quick responses.

Advantages Of Der:-

As compared to the traditional sources, the DER sources are more advantageous in terms of several features such as flexibility, cost etc. Various advantages of DER sources over traditional sources are given in below table (Table-1).

TABLE I. ADVANTAGES OF DER SOURCES OVER TRADITIONAL SOURCES
\begin{tabular}{|l|l|l|l|}
\hline $\begin{array}{l}\text { Sl. } \\
\text { No. }\end{array}$ & Grid related terms & Traditional & DER \\
\hline 1 & Overhead power lines & Long overhead power lines required & $\begin{array}{l}\text { DER eliminates the need of overhead } \\
\text { power lines. }\end{array}$ \\
\hline 2 & Flexibility & $\begin{array}{l}\text { Supply energy: no solution Existing } \\
\text { method and don't allow what is best } \\
\text { for them. }\end{array}$ & More choices \\
\hline 3 & Cost of energy & Higher cost & Lower cost. \\
\hline 4 & Grid reliability & It is less reliable. & $\begin{array}{l}\text { DER reliable. } \\
\text { power at remote } \\
\text { location in unable to provide power at remote } \\
\text { locations. }\end{array}$ \\
\hline 6 & $\begin{array}{l}\text { Faster permitting of } \\
\text { supply }\end{array}$ & $\begin{array}{l}\text { Since they are installed far away, they } \\
\text { facilitate supply slower due to long } \\
\text { transmission lines. }\end{array}$ & $\begin{array}{l}\text { Installation closer to load: facilitates } \\
\text { faster supply. }\end{array}$ \\
\hline 7 & Backup power & No backup. & If required provide backup \\
\hline
\end{tabular}




\begin{tabular}{|l|l|l|l|}
\hline 8 & Environment friendly & $\begin{array}{l}\text { Established method power generation } \\
\text { based on non-renewable resources }\end{array}$ & $\begin{array}{l}\text { DER is cleaner operation; it reduces } \\
\text { emissions because of renewable } \\
\text { resources. }\end{array}$ \\
\hline 9 & Area required & Larger in size larger area occupied. & $\begin{array}{l}\text { Since they are small so they require less } \\
\text { area of infrastructure. }\end{array}$ \\
\hline 10. & Time of planning & More time required for planning. & Short time for planning \\
\hline
\end{tabular}

\section{Characteristics Of Der Technologies:-}

DER resources used numerous technologies to be established. These technologies are selected as the requirement of the uses/applications. Table-2 represents a comparison between different types of DER technologies in terms of advantages, limitations, fuel choice and size (kW).From this table the better type of DER technology can be easily estimated as per their need.

TABLE II. A COMPARISON BETWEEN DIFFERENT DER TECHNOLOGIES

\begin{tabular}{|c|c|c|c|c|}
\hline Technology & Benefits & Drawbacks & Fuel Choice & Size $(k W)$ \\
\hline $\begin{array}{l}\text { Micro- } \\
\text { turbines } \\
\sim 28-33 \% \\
\text { Efficiency }\end{array}$ & $\begin{array}{l}\text { 1) Efficiency outstrips via } \\
\text { thermal retrieval } \\
\text { 2) Thermal yield -domestic } \\
\text { and commercial application } \\
\text { 3) Workable as peaking, base, } \\
\text { back-up. } \\
\text { 4) Commercially accessible in } \\
\text { restricted amount. }\end{array}$ & $\begin{array}{l}\text { Inadequate thermal yield } \\
\text { for industrial } \\
\text { applications }\end{array}$ & $\begin{array}{l}\text { Propane, Natural gas, } \\
\text { Diesel. }\end{array}$ & $\sim 15-250$ \\
\hline $\begin{array}{l}\text { Small Gas } \\
\text { Combustion } \\
\text { Turbines } \\
\sim 25-40 \% \\
\text { Efficiency }\end{array}$ & $\begin{array}{l}\text { 1)Highly Efficient outstrips } \\
\text { via thermal retrieval } \\
\text { 2) Technology commercially } \\
\text { accessible - contender } \\
\text { requirement on-site > } 3 \mathrm{MW} \text { in } \\
\text { the application related to DG. } \\
\text { 3) Can Workable as peaking, } \\
\text { base and back-up } \\
\text { 4) numerous manufacturers } \\
\text { 5) Installation cost- relatively } \\
\text { low. }\end{array}$ & $\begin{array}{l}\text { 1) Sitting and permitting } \\
\text { requirements- } \\
\text { Potentially heavy } \\
\text { 2) Environmental } \\
\text { harms- releases of gases } \\
\text { and noise. } \\
\text { The Possibility of the } \\
\text { requirement of fuel } \\
\text { storage at on-site } \\
\text { position }\end{array}$ & $\begin{array}{l}\text { Methane, Natural gas, } \\
\text { distillate }\end{array}$ & $\begin{array}{l}\sim 3,000- \\
15,000\end{array}$ \\
\hline $\begin{array}{l}\text { Internal } \\
\text { Combustion } \\
\text { Engines } \\
\sim 28-37 \% \\
\text { Efficiency }\end{array}$ & $\begin{array}{l}\text { 1) Immensity power delivered } \\
\text { when Utility out of stock } \\
\text { 2) Quick start-up permits low } \\
\text { sensitive procedures and } \\
\text { provide the required power } \\
\text { without UPSs (emergency } \\
\text { lighting, elevators, HVAC, } \\
\text { various production methods) } \\
\text { 5) Can be efficient when } \\
\text { united with thermal yield } \\
\text { 3)Well established, stable } \\
\text { technology }\end{array}$ & $\begin{array}{l}\text { 1) Insurance policy } \\
\text { effect: Capital used } \\
\text { when back-up generator } \\
\text { is working } \\
\text { 2) Low production cost } \\
\text { usually favors utility } \\
\text { source in all in limited } \\
\text { occasion. } \\
\text { 3) Environmental } \\
\text { harms- discharging } \\
\text { harmful gasses and } \\
\text { sound pollution. } \\
\text { 4) Requirement of fuel } \\
\text { storage system at On- } \\
\text { site locations. }\end{array}$ & $\begin{array}{l}\text { Propane, Diesel, Natural } \\
\text { gas, , Bio-gas, some } \\
\text { petroleum products }\end{array}$ & $<1-6,000$ \\
\hline $\begin{array}{l}\text { Fuel Cells } \\
\sim 45-55 \% \\
\text { Efficiency at }\end{array}$ & $\begin{array}{l}\text { 1) highly efficient } \\
\text { outstrips via hydrogen }\end{array}$ & $\begin{array}{l}\text { 1) Limited commercially } \\
\text { existing devices } \\
\text { 2) Most studies are } \\
\text { going on for the }\end{array}$ & $\begin{array}{l}\text { Direct by hydrogen; } \\
\text { natural gas, propane, } \\
\text { methanol, or other } \\
\text { hydrogen-rich } \quad \text { source }\end{array}$ & $\begin{array}{l}\text { MCFC } \\
\text { (molten } \\
\text { carbonate } \\
\text { fuel cells): }\end{array}$ \\
\hline
\end{tabular}




\begin{tabular}{|c|c|c|c|c|}
\hline $\begin{array}{l}\text { high } \\
\text { temperature } \\
\sim 30-40 \% \\
\text { Efficiency at } \\
\text { Low } \\
\text { temperature }\end{array}$ & 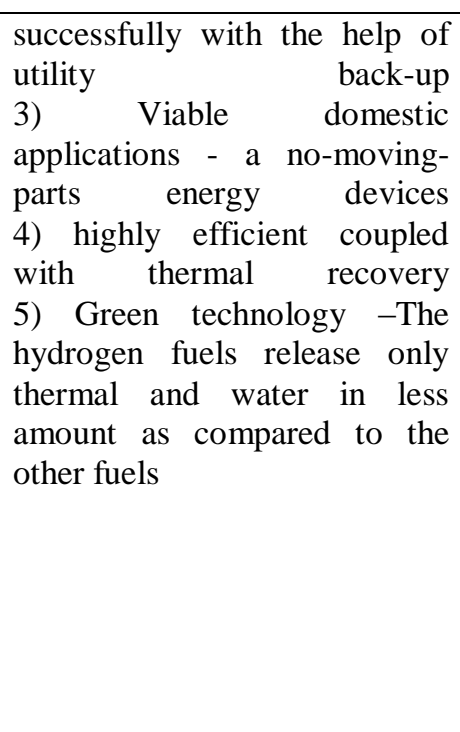 & $\begin{array}{l}\text { automotive related } \\
\text { applications } \\
\text { 3) Fuel reformers are } \\
\text { required for all } \\
\text { applications (efficiency } \\
\text { decreased fuel } \\
\text { :electrical) } \\
\text { 4) Few amount of } \\
\text { harmful emissions are } \\
\text { associated with this } \\
\text { technology and its effect } \\
\text { has changes according to } \\
\text { the state } \\
\text { 5) Cold start for MCFC: } \\
\text { 1-2 days, } \\
\text { PAFC: } 3 \text { hrs, } \\
\text { PEMFC: } 1 \text { hrs, and } \\
\text { SOFC: } 2 \text { minutes }\end{array}$ & through reformer & $\begin{array}{l}\text { 250-2,850 } \\
\text { PAFC:200 } \\
\text { PEMFC: 3- } \\
\text { 250 } \\
\text { SOFC: } \\
\text { 225-2,240 }\end{array}$ \\
\hline Photovoltaic & $\begin{array}{l}\text { 1) Fuel: No variable costs } \\
\text { 2) No moving parts-low } \\
\text { maintenance and good life } \\
\text { 3) Noiseless, emission less } \\
\text { 4) works for peak shaving } \\
\text { 5) Reliable, grown-up } \\
\text { technology }\end{array}$ & 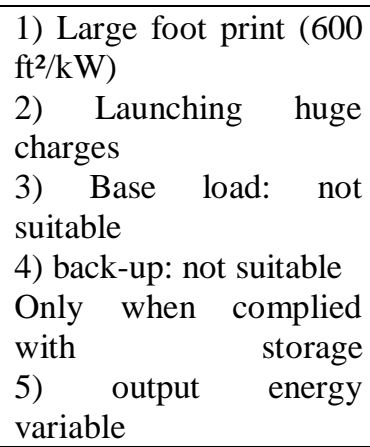 & None & $\begin{array}{l}\text { Limited on } \\
\text { the basis of } \\
\text { the area } \\
\text { availability }\end{array}$ \\
\hline $\begin{array}{l}\text { Large Wind } \\
\text { Turbines }\end{array}$ & $\begin{array}{l}\text { 1) Fuel: Absence of variable } \\
\text { costs } \\
\text { 2) In utility implementation, In } \\
\text { green power cost premium } \\
\text { emissions are not allowed } \\
\text { 3) Grown-up technology } \\
\text { 4) Numerous producers }\end{array}$ & $\begin{array}{l}\text { 1) Siting requirements } \\
\text { must be achieved } \\
\text { 2) Irregular production } \\
\text { due to uneven wind, } \\
\text { which leads to } \\
\text { intermittent energy } \\
\text { output depends on the } \\
\text { wind speed squared or } \\
\text { cubed over the } \\
\text { operational range. This } \\
\text { makes it inappropriate as } \\
\text { a backup or off-grid } \\
\text { applications } \\
3 \text { ) Useful sources are } \\
\text { highly needful for the } \\
\text { purchases and sales of } \\
\text { energy The necessary } \\
\text { 4) The } \\
\text { requirement of the } \\
\text { footprint up to } \\
\text { 100ft } 2 / \mathrm{kW} \text { a }\end{array}$ & $\begin{array}{l}\text { None } \\
\text { Required winds of } \geq 12 \\
\mathrm{mph}\end{array}$ & $<1-1,000$ \\
\hline
\end{tabular}

[Source: Andersen, Reprinted from Public Utility ports, Inc., from the Summer 2001 issue of Fortnightly's Energy Customer Management.]

Economics Of Der:-

Cost is one of the most important factors when considering any product or its installation. However, the cost estimation of a DER technology is highly complex, as it includes the equipment (or capital) cost and labour cost along 
with other expenditures such as installing the equipment. The cost of generated electricity by the DER technology is also determined and compared with the current price of the existing power grid electricity. Table 3 gives a comparison of cost of various DER technologies

TABLE III. VARIOUS DER TECHNOLOGIES ALONG WITH THEIR COST

\begin{tabular}{|c|c|c|c|}
\hline \multicolumn{2}{|c|}{ DER Equipment (Capital Price) } & \multicolumn{2}{|l|}{ DER Equipment (O\&M Price) } \\
\hline DER Equipment & Capital Cost (Rs./kW) & $\begin{array}{l}\text { Time Until Maintenance } \\
\text { Required (hours of operation) }\end{array}$ & $\begin{array}{l}\text { Average } \\
\text { Maintenance } \\
\text { Costs (Rs./kWh) }\end{array}$ \\
\hline Microturbines & $\sim 49,000-77,000$ & $5,000-8,000$ & $\begin{array}{l}\sim 35-112 \\
\text { (estimated) }\end{array}$ \\
\hline Combustion Turbines & $\sim 21,000-70,000$ & $4,000-8,000$ & $\sim 28-35$ \\
\hline $\begin{array}{l}\text { Internal Combustion } \\
\text { Engines }\end{array}$ & $\sim 21,000-56,000$ & $\begin{array}{l}\text { 750-1,000: change oil and oil filter } \\
8,000: \text { rebuild engine head } \\
\text { 16,000: rebuild engine block }\end{array}$ & $\begin{array}{l}\sim 49-105 \text { (natural } \\
\text { gas) } \\
\sim 35-70(\text { diesel })\end{array}$ \\
\hline Fuel Cells & $\sim 49,000-77,000$ & $\begin{array}{l}\text { Yearly: fuel supply system } \\
\text { Yearly: reformer system } \\
\text { 40,000: replace cell stack }\end{array}$ & $\begin{array}{l}\sim 35-70 \\
\text { (estimated) }\end{array}$ \\
\hline Photovoltaics & $\sim 3,15,000-4,20,000$ & Biyearly maintenance check & $\begin{array}{l}\text { Starting } \\
\text { investment/ year } \\
\text { approx } 1 \%\end{array}$ \\
\hline Wind Turbines & $\sim 56,000-2,45,000$ & Biyearly maintenance check & $\begin{array}{l}\text { Starting } \\
\text { investment/ year } \\
\text { approx } 1.5-2 \%\end{array}$ \\
\hline
\end{tabular}

Issues And Challenges In Der:-

As the usability of the DER increases, the distribution grids have to itself bear the responsibility of the transmission systems. However, this entire system contains huge numbers of small generation units on the distribution grid, which leads to some technical challenges such as:

a) Interconnection or integration with grid -The microgrid provides a benchmark between island and interconnected grid [8,9]. Installing micro grid in remote locations is expensive than in normal location as remote location such as island and hilly areas which are far away from utility where transmission lines are unable to reach. At the starting independently a micro grid in island (working separately from the grid), the current producing by the system having highly fluctuations, which causes significant deviations in system parameters such as voltage and frequency, and necessitate the protection of the generator for to be tripped offline during start-up [10],

b) Fixing of tariff- Traditional generation sources tariff is fixed in a particular way considering the initial cost as well as running cost. Individual micro grid installed at different locations would reduce the consumption of energy from the traditional grid which leads to loss for them. Hence a different tariff needs to be found out to balance the traditional grid and DER.

(c)The flow imposed by DER in between independent entities is bi-directional; this cannot be handled by today's existing distribution systems. Some modifications in the existing grid need to be done to accommodate the DER sources. With the increasing need of energy, a micro grid (DER) should be able to fulfill local increased load and robust communication between management system and individual source of energy.

(d) Protection-It is essential to redesign the system in order to familiarize the associated distributed generators with the distribution system. This will enhance the necessity of the distributed intelligence systems and its deeply relying on multi-party communications [3]. Hence one of the most significant threats on DER system is its safety [11].

(e) Balancing and stability of grid-The fundamental problem is that system becomes more complex and fails to control. Since there are number of microgrids or aggregated power sources in a system, it is very complex to handle the control among all the power sources. A solution to overcome this complexity is required. The DER system need to respond to all acute events separately using local information i.e. voltage, frequency and current [4] and hence should provide balance and stability of grid. 


\section{Applications Of Der:-}

The DER users have diverse power requirements. Hospitals required great consistency (back-up power) and power quality (premium power) for the protection of the highly sensitive equipment. Industrial plants normally have huge energy bills, long manufacturing hours, and thermal procedures, and would hence pursue for such a DER applications that include inexpensive energy and combined heat and power. The power need of computer data centers is highly stable, high-quality, continuous (premium power). The existing and being developed in near future, DER technologies are dedicated to fulfill the specific demands of the individuals. Some of the current running DER plans are as:

1. A police station in New York's Central Park saves $\$ 200,000$ over the cost of a line upgrade by using a fuel cell, which is used to run its electronic crime-fighting equipment.

2. The Santa Rita Jail in Dublin, California has established an on-site photovoltaic system and produces 1.18 megawatts. This project has predicted to contribute $\$ 15$ million as net savings over the 25 -year life of the project.

3. A natural gas distribution company installed a natural gas powered microturbine and make it jointly work/generation of the power with the plant's liquefaction section for supplying heat in the winter and cooling in the summer to serve over 240 communities in Minnesota [5].

\section{Conclusions:-}

An alternate distributing system DER is better over existing distributing system. Using concept of micro grids (DER) makes the system more reliable, more efficient, reduces transmission losses and lowers the cost of energy. Using DERs, we generate electricity from renewable resources, blackout chances get reduced and energy will also reach in remote locations to isolated communities. It is well known that various renewable energy provisions like solar and wind have been used in smart grids. But due to low capacity and size of renewable energy, it cannot be used complete energy pride by consumers. Therefore we need to develop control and common algorithm to emphasize efficient and reliable development. However, challenges exist like integrating with existing grid, complexity of micro grids, and installation cost of micro grids can be removed with the future research. So, developments in DER concept need more efforts to resolve the challenges.

\section{Acknowledgment:-}

Authors would like to express the gratitude to the Research Mentors of Accendere Knowledge Management Services Pvt. Ltd. for their comments on an earlier version of the manuscript. Although any errors are our own and should not tarnish the reputations of these esteemed persons.

\section{References:-}

1. Proceeding of IEEE, volume 99(6)- June 1,2011, prof. R.H Lassester(smart distribution : coupled microgrids).

2. US department of energy by the national renewable energy laboratory, DOE/GO-102002-1520 May 2002

3. Tselepis, S., Tentzerakis, S., Lymberopoulos, N., Chaviaropoulos, P., Agoris, D. CIGRE, Study Committee WG D1.18: Materials and emerging technologies.31st August - 5th Sept. 2003. Scandic Marina Palace Hotel, Turku, Finland.

4. R.H Lassester, Smart distribution : coupled microgrids, Proceeding of IEEE, volume 99(6)- June 1,2011, pp.1074-1082.

5. https://www.wbdg.org/resources/distributed-energy-resources-der

6. Table 2:US department of energy by the national renewable energy laboratory, DOE/GO 102002-1520 May 2002

7. Report on A Review of Distributed Energy Resources, DNV GL Energy,Energy Advisory Arlington, VA ,September 2014.

8. PDF Ferera,Distributed Energy Resources Integration Challenges in Low-Voltage Networks: Voltage Control Limitations and Risk of Cascading, IEEE transactions on Sustainable Energy,vol.4,no.1, January 2013,pp.8288.

9. A. Salam, A. Mohamed and M. A. Hannan,TECHNICAL CHALLENGES ON MICROGRIDS,ARPN Journal of Engineering and Applied Sciences, vol 3,No.6, December 2008.

10. Paul Pabst, ieee smart grid, newsletter, challenges on micro grid deployment, February 2017, http://smartgrid.ieee.org/newsletters/february-2017/challenges-of-microgrid-deployment

11. A. Salam, A. Mohamed and M. A. Hannan,Technical Challenges on Microgrids,,ARPN Journal of Engineering and Applied Sciences, vol 3,No.6, December 2008 